\title{
Heavy metals uptake and translocation by lettuce and spinach grown on a metal-contaminated soil
}

\author{
Mamdouh Alsayed. Eissa*1, Osama Elqusy. Negim² \\ ${ }^{1}$ Department of Soils and Water, Faculty of Agriculture, Assiut University, Assiut 71526, Egypt \\ ${ }^{2}$ Department of Soils and Water, Faculty of Agriculture, Sohag University, Sohag 82524, Egypt \\ *Corresponding author: mamdouh.eisa@aun.edu.eg
}

\begin{abstract}
Nowadays, using sewage wastewaters in the irrigated agriculture is commune creating hazardous environment impacts. Assessment of these negative effects is vital issue to prevent heavy metals to be introduced in the food chain. Field and laboratory studies were conducted at Arab-El-Madabegh village, Assiut Governorate, Egypt, in order to evaluate the heavy metals concentrations in the edible parts of lettuce and spinach plants which irrigated with sewage water $(\mathrm{SW})$. The obtained results indicated that, the soils of the studied site were contaminated by heavy metals. Zinc, $\mathrm{Cu}, \mathrm{Pb}, \mathrm{Cd}$ and $\mathrm{Ni}$ concentrations in the edible portions of the studied vegetables plants ranged between 75- 110, 15 - 17, 2 - 5, 1.0 -3.5 and 1.0 -2.5 $\mathrm{mg} \mathrm{kg}^{-1}$, respectively. The obtained results showed that the concentrations of $\mathrm{Zn}, \mathrm{Pb}, \mathrm{Cd}$ and $\mathrm{Ni}$ in the edible parts of the studied plants were higher than the permissible limit levels but those of $\mathrm{Cu}$ were within the safe limit levels. It is worthy to mention that the irrigated edible vegetable crops with SW should be avoided. This study highlights the potential hazard for human health due to the uptake of high concentrations of heavy metals especially $\mathrm{Zn}, \mathrm{Ni}, \mathrm{Cd}$ and $\mathrm{Pb}$ by the studied vegetable crops
\end{abstract}

Keywords: Contaminated soils, Safe limits, Human consumption, Heavy metals.

\section{Introduction}

Water is important for all human activities. Water accounted for about $50-97 \%$ of plant and animal bodies; moreover, it is a vital for all biological processes in plant and animal cells (Buchholz, 1998). Fresh water recourses in the world are very limited and only $0.6 \%$ of the total world water resources is fresh water (Fakayode, 2005). Fresh water resources have been decreased in an alarming rate and they may not able to meet the requirements of the different human in the future (Qadir et al., 2008). The agriculture sectored uses about $80 \%$ of the water resources in irrigation purposes. Most of agriculture lands located near urban are irrigated by wastewater because of the low availability of fresh water for crop production (Ghimire, 1994). 
The increasing of population and human activities enlarged the volume of sewage wastewaters (SW) (Qadir et al., 2008). In many developing countries, these water resources may, in most cases, use in the form of diluted raw sewage, even if it is considered unlawful (Huibers et al., 2004). Wastewaters quality differs both between and within countries. In many poor countries in Africa, Asia and Latin America, the untreated wastewaters are used widdly in agriculture production, while in middle-income countries treated wastewater is used (Faruqui et al., 2004).

The use of sewage wastewater in the irrigation provides the soil with nutrients and organic matter; moreover, it is an inexpensive system for wastewater disposal (Ghosh et al., 2012). In many situations, Egyptian farmers use wastewater in irrigation even when the fresh one is available, due to the high profits earned by using waste one. Sewage wastewaters (SW) are usually rich in nitrogen $(\mathrm{N})$, phosphorus $(\mathrm{P})$ and potassium $(\mathrm{K})$ and farmers use these waters as low price fertilizers (Chhabra, 1989). Nutrient concentrations in sewage waste waters are varied widely and Chhabra (1989) found that the SW contained 48.3, 7.6, 72.4 and 34.6 mg L $\mathrm{L}^{-1}$ of $\mathrm{N}, \mathrm{P}, \mathrm{K}$ and $\mathrm{S}$, respectively besides micronutrients contents of $0.34,10.8,0.2$ and $0.36 \mathrm{mg} \mathrm{L}^{-1}$ for $\mathrm{Zn}, \mathrm{Fe}, \mathrm{Cu}$ and $\mathrm{Mn}$, respectively. Therefore, ten SW irrigations of $7.5 \mathrm{~cm}$ each could add about $362,58,540$ and $260 \mathrm{~kg} \mathrm{ha}^{-1}$ of $\mathrm{N}, \mathrm{P}, \mathrm{K}$ and $\mathrm{S}$, respectively, to the soil which are more than the nutrient requirements of most crops (Eissa, 2016). These findings recapitulate that wastewater has a great potential as a manure when it is used to irrigate crops (Khurana and Singh, 2012). Wastewaters contain high levels of $\mathrm{Cd}, \mathrm{Ni}, \mathrm{Pb}, \mathrm{Cr}$ and As. These elements are not essential for plant and animal nutrition (Kanwar and Sandha, 2000). The use of sewage wastewater can in the irrigation processes may cause remarkable increases in soil heavy metal concentrations (Khan et al., 2008; Ghosh et al., 2012). The raising of soil heavy metal content will lead to introduce the metals to the vegetables and cereals crops causing a potential health risk to human and animal (Singh et al., 2010; Gupta et al., 2011). The concentrations of heavy metals in plants cultivated on wastewater-irrigated soils are significantly higher than in those grown on fresh water-irrigated ones (Khan et al., 2008; Singh et al., 2010; Gupta et al., 2011). The use of sewage wastewater to irrigate plants is an old acction in many areas in Egypt due to the complexity of its treatment and disposal as well as the scarcity of fresh irrigation water. Its use is obligatory in order to provide foods to the ever-increasing population. It may cause soils and plants to be contaminated with heavy metals. The present study was undertaken to assess heavy metal contents of lettuce and spinach plants irrigated with sewage wastewater.

\section{Materials and Methods}

\subsection{Site description and sampling}

Composite plant samples of spinach (Spinacia olivera L) cv. Balady and lettuce (Lactuca sativa L.) cv. Balady irrigated with sewage wastewater were collected from Arab Elmadabegh village, Assiut governorate, Egypt which are located at $27^{\circ} 12^{-} 16.67^{=} \mathrm{N}$ latitude and $31^{\circ} 09^{-} 36.86^{=} \mathrm{E}$ longitude to evaluate levels of some heavy metals $(\mathrm{Zn}, \mathrm{Cu}, \mathrm{Pb}, \mathrm{Ni}$ and $\mathrm{Cd})$ in these vegetables plants. The soils in this village have been irrigated by raw sewage water for more than 50 years. Table 1 shows the main properties of the studied site. Each composite sample included the edible portion of ten plants of each crop. Inorganic wastes were removed from plant samples by washing in $0.1 \mathrm{HCl}$ and Tween 80 . The plant samples were washed twice by tap water, rinsed by distilled water, air-dried, ovendried at $70{ }^{\circ} \mathrm{C}$ to a constant weight, ground and then were kept for chemical analysis. Soil $(0-30 \mathrm{~cm})$ and sewage wastewater samples were also taken from the experimental site. 
Table 1. Some physical and chemical characteristics of the soil in the studied site

\begin{tabular}{lcc}
\hline Soil properties & $0-30 \mathrm{~cm}$ & Permissible limits \\
\hline Clay instate of $\mathrm{P}$ & 110 & \\
Silt $(\mathrm{gkg})$ & 180 & \\
Sand $(\mathrm{gkg})$ & 710 & \\
Texture & Sandy loam & \\
$\mathrm{CaCO}(\mathrm{gkg})$ & 70 & \\
$\mathrm{pH}(1: 2)$ & 7.85 & \\
$\mathrm{CEC}(\mathrm{cmolkg})$ & 18 & \\
Total Organic-C $(\mathrm{gkg})$ & 25.2 & \\
EC $(1: 2)(\mathrm{dS} / \mathrm{m})$ & 1.8 & \\
Available-Zn & 7.5 & \\
Available-Cu & 5.0 & \\
Available-Pb & 6.4 & $30-300$ \\
Available-Cd & 0.40 & 300 \\
Available-Ni & 1.20 & 30 \\
Total-Zn & 620 & \\
Total-Cu & 310 & \\
Total-Pb & 300 & \\
Total-Cd & 6.5 & \\
Total-Ni & 50 & \\
\hline
\end{tabular}

*Permissible limits according to European Union Standards (EU, 2002) and U.S. Environmental Protection Agency (USEPA, 1997).

\subsection{Soil, water and plant analysis}

The physical and chemical properties of the studied soil samples were determined according to Burt (2004) as they are shown in Table 1. The available heavy metals $(\mathrm{Zn}, \mathrm{Cu}, \mathrm{Pb}, \mathrm{Cd}$ and $\mathrm{Ni}$ ) were extracted from the soil samples using a $0.005 \mathrm{M}$ DTPA (diethylen triamine penta acetic acid) solution buffered at $\mathrm{pH} 7.3$ as described by Lindsay and Norvell (1978). To determine the total heavy metals, the soil sample was digested according to the procedure given by the US EPA (1996). A known volume of sewage wastewater sample was oven-dried and then was digested using concentrated $\mathrm{HNO}_{3}$ at $80{ }^{\circ} \mathrm{C}$ (Table 2). The soil sample was air-dried and sieved with a 2-mm diameter sieve and kept for analysis. The metals in the soil, water and plant digest as well as DTPA soil extract were measured using the Inductivity Coupled Plasma Emission Optical Emission Spectrometry (ICP-OES thermo iCAP 6000 series). The ground plant samples were digested using concentrated acids of $\mathrm{HNO}_{3}$ and $\mathrm{HClO}_{4}$. The reference material (SRM 1547) was measured at the same time for quality assurance. The obtained results of the reference material indicated that the determined levels are within the range of certified value. Recovery of $\mathrm{Zn}, \mathrm{Cu}, \mathrm{Cd}$, $\mathrm{Ni}$ and $\mathrm{Pb}$ was 104, 101, 97, 98 and 105\%.

\subsection{Data analysis}

The one-way ANOVA was run by SPSS software (version 15) to test the statistically significant difference between the three treatments. Moreover, Duncan test (at $5 \%$ probability) was performed to compare between means of the tested treatments. 
Table 2. Chemical analysis of the irrigation sewage wastewater in the studied site

\begin{tabular}{ccccccc}
\hline $\mathrm{pH}$ & $\begin{array}{c}\mathrm{EC} \\
\left(\mathrm{dS} \mathrm{m}^{-1}\right)\end{array}$ & $\mathrm{Zn}$ & $\mathrm{Cu}$ & $\mathrm{Pb}$ & $\mathrm{Cd}$ & $\mathrm{Ni}$ \\
\hline 7.25 & 3.5 & 0.45 & 0.28 & 1.3 & 0.06 & 0.06 \\
& $\mathrm{PL}^{*}$ & 0.20 & 0.20 & 5.0 & 0.01 & 0.20 \\
\hline
\end{tabular}

*Permissible limits according to FAO (1985). Each value represents the mean of three replicates.

\section{Results}

\subsection{Soil and sewage wastewater heavy metals}

The heavy metal content of the irrigation source and soil in the experimental site was analyzed and the data are presented in Tables 1 and 2. The concentrations of $\mathrm{Zn}, \mathrm{Cu}, \mathrm{Pb}, \mathrm{Cd}$ and $\mathrm{Ni}$ in the investigated wastewater sample were $0.45,0.28,1.30,0.06$ and $0.06 \mathrm{mg} \mathrm{L}^{-1}$, respectively. The total concentrations of $\mathrm{Zn}, \mathrm{Cu}, \mathrm{Pb}, \mathrm{Cd}$ and $\mathrm{Ni}$ in the studied soil sample were 620 to 310,300 , 6.5 and $130 \mathrm{mg} \mathrm{kg}^{-1}$, respectively. The total content of soil heavy metal determines the level of contamination.
3.2. Heavy metals concentrations in the roots and shoots of lettuce and spinach plants

The concentrations of $\mathrm{Zn}$ in the shoot and root of the studied plants ranged between 75 and $200 \mathrm{mg}$ $\mathrm{kg}^{-1}$ (Figure 1). The concentrations of $\mathrm{Zn}$ in the root and shoot of lettuce were 120 and 75 while those of spinach were 200 and $110 \mathrm{mg} \mathrm{kg}^{-1}$, respectively. The highest $\mathrm{Zn}$ concentration was recorded in the root of lettuce and spinach plants. The root and shoot of spinach plants significantly $(P<0.05)$ contained higher levels of $\mathrm{Zn}$ rather than those of lettuce.

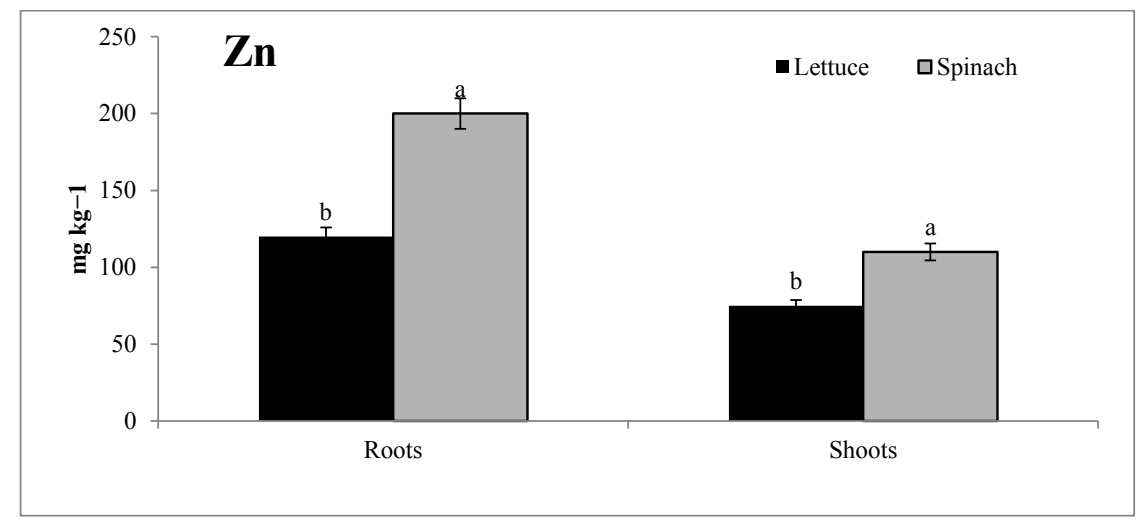

Figure 1. Zinc $(\mathrm{Zn})$ concentrations $\left(\mathrm{mg} \mathrm{kg}^{-1}\right)$ in the roots and shoots of lettuce and spinach plants

Means denoted by the same letter indicate no significant difference according to Duncan's test at $P<0.05$. 
Copper $(\mathrm{Cu})$ concentrations in the shoot and root of lettuce and spinach plants varied from 15 and $30 \mathrm{mg} \mathrm{kg}^{-1}$ (Figure 2). The highest value of $\mathrm{Cu}$ concentration was recorded for the root of spinach and lettuce (30 and 35 $\mathrm{mg} \mathrm{kg}^{-1}$ ) while the lowest concentrations were obtained in the shoots of the two mentioned plants (15 and 17 $\left.\mathrm{kg}^{-1}\right)$. The root and shoot of spinach plants significantly $(P<0.05)$ contained higher levels of $\mathrm{Cu}$ rather than those of lettuce.

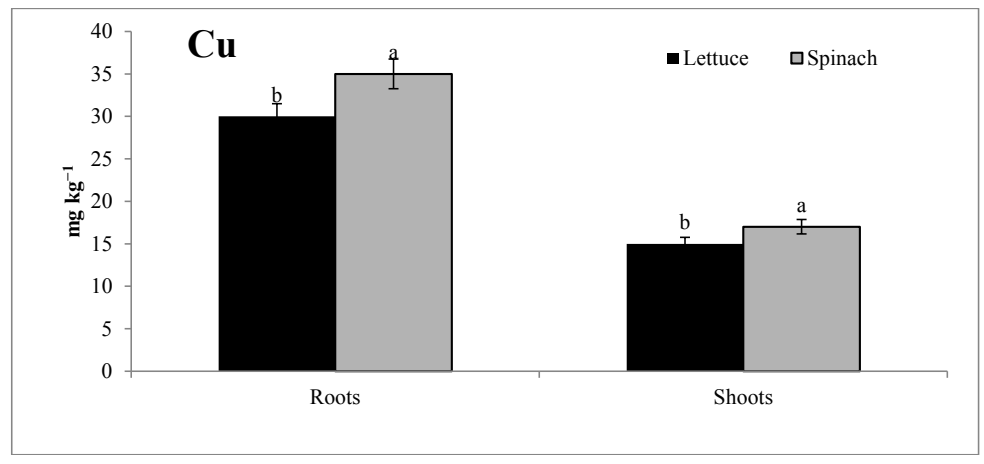

Figure 2. Copper $(\mathrm{Cu})$ concentrations $\left(\mathrm{mg} \mathrm{kg}^{-1}\right)$ the roots and shoots of lettuce and spinach plants

Means denoted by the same letter indicate no significant difference according to Duncan's test at $P<0.05$.

Lead $(\mathrm{Pb})$ content of the root and shoot of lettuce and spinach plants differed between 2.0 and 20.0 $\mathrm{mg} \mathrm{kg}^{-1}$ (Figure 3). The concentrations of $\mathrm{Pb}$ in the roots of lettuce and spinach were 14 and $20 \mathrm{mg}$ $\mathrm{kg}^{-1}$ while in the shoots these concentrations were
2.0 and $5.0 \mathrm{mg} \mathrm{kg}^{-1}$, respectively. Lead $(\mathrm{Pb})$ concentrations in the root and shoots of spinach were significantly higher than those in lettuce; moreover, the root contained very higher concentrations compared to the shoot.

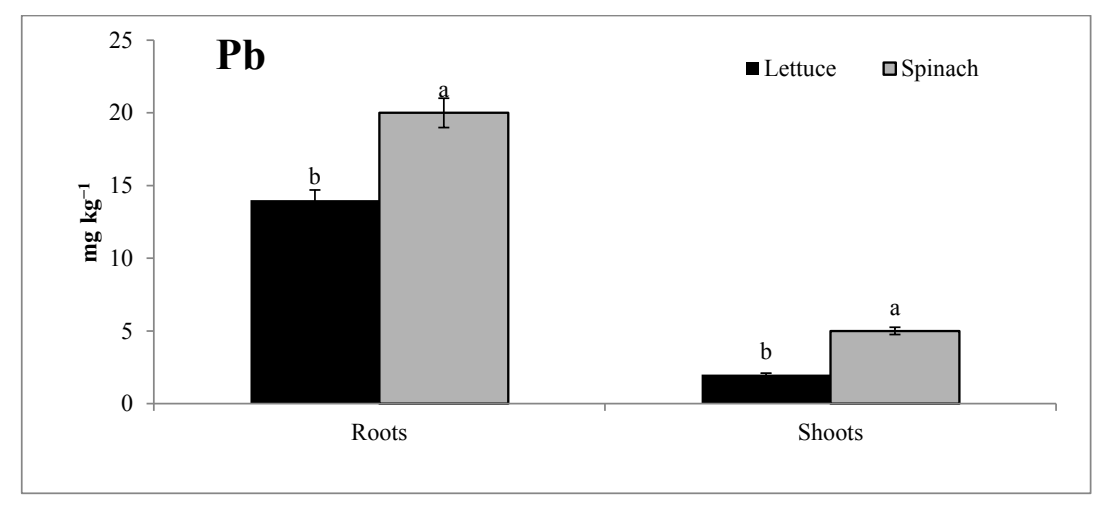

Figure 3. Lead $(\mathrm{Pb})$ concentrations $\left(\mathrm{mg} \mathrm{kg}^{-1}\right)$ in the roots and shoots of lettuce and spinach plants 
The edible parts of lettuce and spinach plants contained Cd levels varied between 1.50 and $20.0 \mathrm{mg} \mathrm{kg}^{-1}$ (Figure 4). The concentrations of $\mathrm{Cd}$ in the shoot of lettuce and spinach were 1.50 and $3.0 \mathrm{mg} \mathrm{kg}^{-1}$; while in roots were 15 and $20 \mathrm{mg} \mathrm{kg}^{-1}$, respectively. The root and shoot of spinach plants significantly $(P<$ 0.05 ) contained higher levels of $\mathrm{Cd}$ rather than those of lettuce

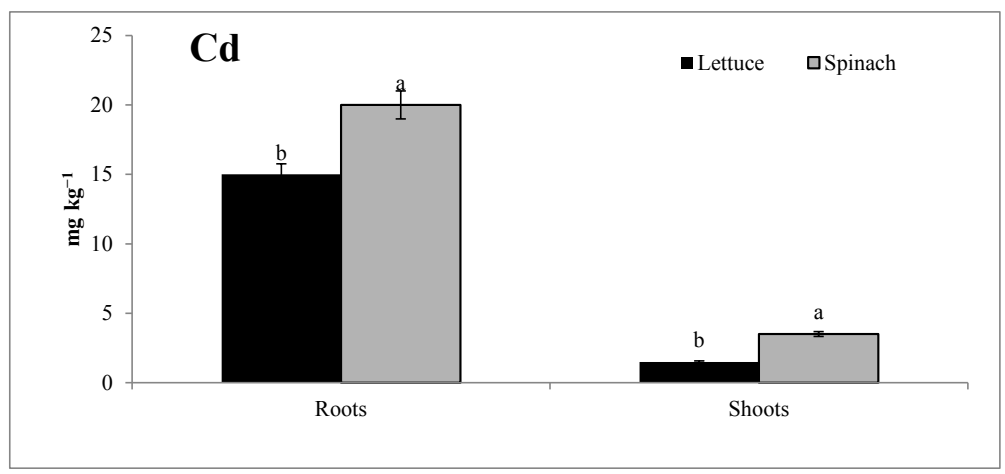

Figure 4. Cadmium $(\mathrm{Cd})$ concentrations $\left(\mathrm{mg} \mathrm{kg}^{-1}\right)$ in the roots and shoots of lettuce and spinach plants

Means denoted by the same letter indicate no significant difference according to Duncan's test at $P<0.05$.

Nickel (Ni) levels in the edible parts of lettuce and spinach plants varied from 1.5 to $15 \mathrm{mg} \mathrm{kg}^{-1}$ (Figure 5). The concentrations of $\mathrm{Ni}$ in the shoot of lettuce and spinach were 1.0 and $2.5 \mathrm{mg} \mathrm{kg}^{-1}$; while in the roots were 12 and
$15 \mathrm{~kg}^{-1}$ respectively. Nickel (Ni) concentrations in the root and shoots of spinach were significantly $(P<0.05)$ higher than those in lettuce; moreover, the root contained very higher concentrations compared to the shoot.

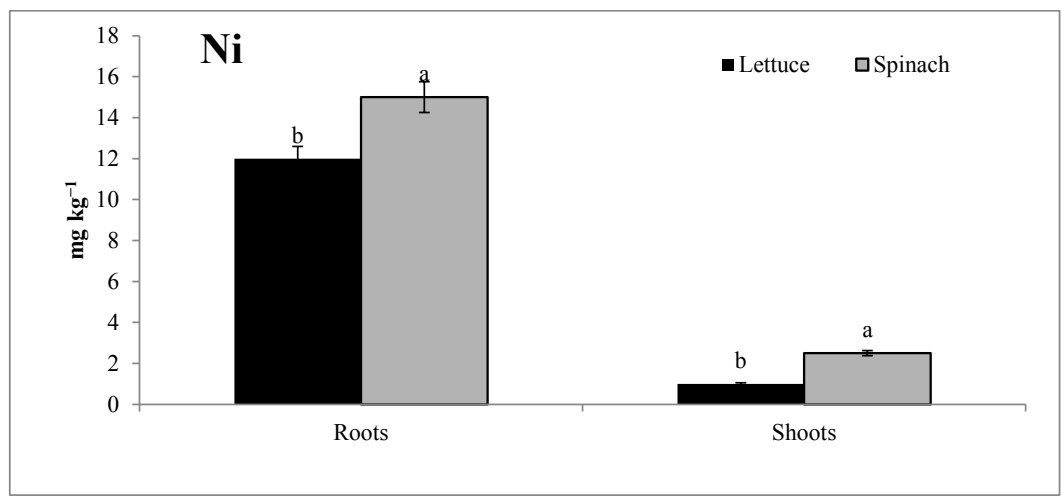

Figure 5. Nickel (Ni) concentrations $\left(\mathrm{mg} \mathrm{kg}^{-1}\right)$ in the roots and shoots of lettuce and spinach plants

Means denoted by the same letter indicate no significant difference according to Duncan's test at $P<0.05$. 


\subsection{Translocation of heavy metals from soil to roots and from roots to shoots}

The behavior of heavy metal accumulation by lettuce and spinach plants was investigated by calculation of root-shoot and soil-root transfer of the studied metals and the data are shown in Table 3. The bioaccumulation factor (BAF) was calculated from the metal in the root divided by the available metal in the soil. The BAC is used to assess the soil-root transfer of metal (Eissa and Ahmed, 2016). The values of BAC ranged between 1.9 and 50.0 and these values significantly differed between the investigated metals as well as between lettuce and spinach plants. The values of BAF of lettuce were 16.0, 6.0, 11.7, 37.5 and 1.9 for $\mathrm{Zn}, \mathrm{Cu}, \mathrm{Pb}, \mathrm{Cd}$ and $\mathrm{Ni}$, respectively. The values of BAF of spinach were 26.7, 7.0, 16.7, 50.0 and 2.30for $\mathrm{Zn}, \mathrm{Cu}, \mathrm{Pb}, \mathrm{Cd}$ and $\mathrm{Ni}$, respectively. The
$\mathrm{BAC}$ of spinach was higher than that of lettuce for all the studied metals. The values of BAC of Cd were the highest either in the case of lettuce and spinach plants. The BAC values were found in the order: $\mathrm{Cd}$ $>\mathrm{Zn}>\mathrm{Pb}>\mathrm{Cu}>\mathrm{Ni}$.

The translocation factor (TF) was calculated from the metal in the shoot divided by that found in the root. The TF is used to assess the root-shoot transfer of metal (Eissa and Ahmed, 2016). In the current study the values of TF ranged between 0.08 and 0.63 and these values differed significantly from metal to metal as well as between the studied plants. The TF values were found in the order: $\mathrm{Zn}>\mathrm{Cu}>\mathrm{Pb}>\mathrm{Cd}>\mathrm{Ni}$. The highest TF value was recorded in the case of $\mathrm{Zn}$ and $\mathrm{Cu}$, while the lowest were found in the case of $\mathrm{Pb}, \mathrm{Cd}$ and $\mathrm{Ni}$. The TF values of $\mathrm{Pb}, \mathrm{Cd}$ and $\mathrm{Ni}$ in the case of spinach were higher than those of lettuce.

Table 3 Translocation of heavy metals from soil to roots and from roots to shoots

\begin{tabular}{|c|c|c|c|c|c|c|c|c|c|c|}
\hline \multirow{2}{*}{ Plant } & \multicolumn{5}{|c|}{ BAF } & \multicolumn{5}{|c|}{$\mathrm{TF}$} \\
\hline & $\mathrm{Zn}$ & $\mathrm{Cu}$ & $\mathrm{Pb}$ & $\mathrm{Cd}$ & $\mathrm{Ni}$ & $\mathrm{Zn}$ & $\mathrm{Cu}$ & $\mathrm{Pb}$ & $\mathrm{Cd}$ & $\mathrm{Ni}$ \\
\hline Lettuce & $16.00 \mathrm{~b}$ & $6.0 \mathrm{a}$ & $11.7 \mathrm{~b}$ & $37.5 \mathrm{~b}$ & $1.9 \mathrm{~b}$ & $0.63 \mathrm{a}$ & $0.50 \mathrm{a}$ & $0.14 \mathrm{~b}$ & $0.10 \mathrm{~b}$ & $0.08 \mathrm{~b}$ \\
\hline Spinach & $26.67 \mathrm{a}$ & $7.0 \mathrm{a}$ & $16.7 \mathrm{a}$ & $50.0 \mathrm{a}$ & $2.3 \mathrm{a}$ & $0.55 \mathrm{~b}$ & $0.49 \mathrm{a}$ & $0.25 \mathrm{a}$ & $0.18 \mathrm{a}$ & $0.17 \mathrm{a}$ \\
\hline
\end{tabular}

$\mathbf{B A F}=$ metal concentration in the root/ the concentration of the available metal in the soil.

TF = metal concentration in the shoot/ metal concentration in the root.

Means denoted by the same letter indicate no significant difference according to Duncan's test at $\mathrm{P}<0.05$. 


\section{Discussion}

\subsection{Heavy metals in the studied soil and sewage wastewater}

The levels of $\mathrm{Zn}, \mathrm{Cu}$ and $\mathrm{Cd}$ were higher than the permissible limits of the irrigation water according to the FAO (1985). On the other hand, $\mathrm{Pb}$ and $\mathrm{Ni}$ concentrations in this wastewater sample were lower than the FAO (1985) allowable limits. The higher $\mathrm{Zn}, \mathrm{Cu}$ and $\mathrm{Cd}$ concentrations recorded in the studied water sample of Arab-Elmadabegh, where the sewage wastewater collection and treatment station of Assiut city is located.

The total concentrations of all the investigated metals $(\mathrm{Zn}, \mathrm{Cu}, \mathrm{Pb}, \mathrm{Ni}$ and $\mathrm{Cd})$ in soil were above the maximum permissible limits recorded by EU (2002) and USEPA (1997). These obtained values confirmed that the soil under study is contaminated with these heavy metals. Similar results were found by Eissa et al. (2016). The long-term use of treated and untreated wastewater in irrigation was reported to cause significant buildup of the heavy metals in the soils (Khan et al., 2008; Ghosh et al., 2012; Eissa, 2014).

\subsection{Heavy metals in the roots and shoots of lettuce and spinach plants}

The root and shoot of spinach plants contained higher levels of $\mathrm{Zn}$ rather than those of lettuce. These results were confirmed by Eissa (2016) who found that the concentrations of $\mathrm{Zn}$ in the leaves of spinach and lettuce grown on a metal contaminated soil were 225 and $78 \mathrm{mg} \mathrm{kg}^{-1}$, respectively. According to WHO/FAO (2007) and EU (2006), the maximum permissible $\mathrm{Zn}$ limit for human consumption is between 60 and $80 \mathrm{mg}$ $\mathrm{kg}^{-1}$ dry weights. Thus, the concentrations of $\mathrm{Zn}$ in the shoot of lettuce were less than the allowable level and these plants are safe for human consumption. The shoot of spinach contained $\mathrm{Zn}$ concentration more than the allowable levels and is not safe for human consumption.

The maximum permissible concentration of $\mathrm{Cu}$ in the edible parts for human consumption is $40 \mathrm{mg} \mathrm{kg}^{-1}$ dry weight (WHO/FAO, 2007; EU, 2006). Therefore, the edible parts of these plants are safe to be used by human being. The obtained results were confirmed by Eissa (2016) who reported that the concentrations of $\mathrm{Cu}$ in the leaves of lettuce and spinach grown on a metal contaminated soil were 16 and $15 \mathrm{mg} \mathrm{kg}^{-1}$, respectively.

According to WHO/FAO (2007) and EU (2006) the maximum $\mathrm{Pb}$ permissible level for human consumption is $0.3 \mathrm{mg} \mathrm{kg}^{-1}$ dry weight. The concentrations of $\mathrm{Pb}$ in the shoot of lettuce and spinach were 2.0 and $5.0 \mathrm{mg} \mathrm{kg}^{-1}$, respectively. Thus, the concentrations of $\mathrm{Pb}$ in the edible plant parts were higher than this permissible level indicating their unsafe to be used. The results indicated that sewage wastewater use in irrigating these vegetables caused a significant increase in $\mathrm{Pb}$ content in their edible portions. The obtained results are in an agreement with those of Rattan et al. (2005) and Lone et al. (2003). Eissa (2016) found that the concentrations of $\mathrm{Pb}$ in the leaves of spinach and lettuce grown on a metal contaminated soil were 1.9 and $0.3 \mathrm{mg} \mathrm{kg}^{-1}$, respectively.

WHO/FAO (2007) and EU (2006) indicated that the maximum permissible level of $\mathrm{Cd}$ for human consumption is $0.2 \mathrm{mg} \mathrm{kg}^{-1}$ dry weight. The concentrations of $\mathrm{Cd}$ in the shoot of lettuce and spinach were 1.50 and $3.0 \mathrm{mg} \mathrm{kg}^{-1}$, respectively. Thus, the concentrations of $\mathrm{Cd}$ in these edible parts were higher than that permissible limit which they are not safe to be consumed. The irrigation of these vegetables with sewage wastewater caused a significant increase in $\mathrm{Cd}$ concentrations in their edible portions. These coincide with those of Rattan et al. (2005) and Lone et al. (2003). 
The maximum permissible Ni level for human consumption is $1.5 \mathrm{mg} \mathrm{kg}^{-1}$ dry weight (WHO/FAO, 2007; EU, 2006). The concentrations of $\mathrm{Ni}$ in the shoot of lettuce and spinach were 1.0 and $2.5 \mathrm{mg}$ $\mathrm{kg}^{-1}$, respectively. Thus, levels of $\mathrm{Ni}$ in the edible parts of these plants were higher than its permissible limit level. The use of sewage wastewater in irrigation these vegetables caused a significant increase in $\mathrm{Ni}$ concentrations in the edible portions. These results are in the same line with those of Rattan et al. (2005) and Lone et al. (2003). The prolonged application of treated and untreated wastewaters results in significant buildup of heavy metals in the soils (Khan et al., 2008; Ghosh et al., 2012; Durán et al., 2016) and grown vegetables and cereals which they subsequently transfer to the food chain causing potential health risk to consumers (Singh et al., 2010; Gupta et al., 2011). Heavy metals concentrations in plants grown on wastewater-irrigated soils were reported to be significantly higher than those grown on fresh water-irrigated soils (Khan et al., 2008; Singh et al., 2010; Gupta et al., 2011).

\subsection{Translocation of heavy metals from soil to roots and from roots to shoots}

The data of the current study indicated that the value of Cd soil-root transfer was the highest one. The high rate of the soil-root transfer in the case of $\mathrm{Cd}$ may be due to the high mobility of this metal compared to the other studied metals (Eissa et al., 2016). The values of root-shoot transfer of the investigated metals were less than one indicating that the lettuce and spinach plants absorbed more metals in roots and transfered less concentrations to the shoots (Eissa and Ahmed, 2016). In general, the root-shoot transfer of $\mathrm{Zn}$ and $\mathrm{Cu}$ was higher than that of $\mathrm{Pb}, \mathrm{Cd}$ and Ni. Similar results were found by Eissa (2016) and Eissa et al. (2014). The higher rate of the TF values in the case of $\mathrm{Zn}$ and $\mathrm{Cu}$ may be due to they are essential micronutrients (Marschner, 1995; Amin and Eissa, 2017) while $\mathrm{Pb}, \mathrm{Cd}$ and $\mathrm{Ni}$ are toxic metals. The plants tend to accumulate the heavy metal in the roots and transfer a few concentrations to the shoots (Wozny, 1995); Voutsa et al., 1996; Verdejo et al., 2016). Kadukova et al. (2004) found that the $\mathrm{Pb}$ stored in plant roots was from 93 to $98 \%$ from the total $\mathrm{Pb}$ absorbed by these plant roots. The root and shoot of spinach plants contained higher levels of $\mathrm{Pb}$ rather than those of lettuce. High concentrations of $\mathrm{Cd}$ and $\mathrm{Pb}$ in the roots of lettuce and spinach plants may be related to its low translocation within plants (Voutsa et al., 1996, Kadukova et al., 2004; Eissa, 2016).

\section{Conclusion}

It might be concluded that heavy metals could accumulated in the edible vegetables that irrigated with sewage wastewater. In this study, the obtained results showed that the concentrations of $\mathrm{Pb}, \mathrm{Cd}$ and $\mathrm{Ni}$ in the edible parts of some vegetables were higher than their permissible limit levels. Therefore, the edible parts of lettuce and spinach plants are not safe for human consumption. It is worthy to mention that irrigated edible vegetable crops irrigated with sewage wastewater should be avoided and Egyptian guidelines should be developed for the reuse of these waters in agriculture. Therefore, it is recommended to never use sewage wastewater to irrigate vegetables unless it is obligated. Sewage wastewater might be used to irrigate other plants such as woody trees that can be used as a wind break as well as energy producer plants.

\section{Acknowledgements}

Financial support from the Faculty Agriculture, Assiut University, Egypt is greatly acknowledged. 


\section{References}

Amin, A.A., Eissa, M.A. 2017. Biochar effects on nitrogen and phosphorus use efficiencies of zucchini plants grown in a calcareous sandy soil. Journal of Soil Science and Plant Nutrition. 17, 912-921.

Buchholz, R.A. 1998. Principles of environmental management. The Greetings of Business.

Burt, R. 2004. Soil survey laboratory methods manual. Soil Survey Investigations Report No. 42, Version 4.0, Natural Resources Conservation Service, United States Department of Agriculture.

Chhabra, R. 1989. Sewage water, utilization through forestry. National Printers, Old Market, West Patel Nagar, New Delhi, India, p: 1-9.

Durán, P., Acuña, J.J., Armada, E., López-Castillo, O.M., Cornejo, P., Mora, M.L., Azcón, R. 2016. Inoculation with selenobacteria and arbuscular mycorrhizal fungi to enhance selenium content in lettuce plants and improve tolerance against drought stress. Journal of Soil Science and Plant Nutrition. 16, 201-225.

Eissa, M.A. 2014. Performance of river saltbush (Atriplex amnicola) grown on contaminated soils as affected by organic fertilization. World Applied Science Journal. 30, 1877-1881.

Eissa, M.A., Ghoneim, M.F., Elgharably, G.A., AbdElRazek, M. 2014. Phytoextraction of nickel, lead and cadmium from metals contaminated soils using different field crops and EDTA. World Applied Science Journal. 32, 1045-1052.

Eissa, M.A. 2016. Phosphate and organic amendments for safe production of okra from metalcontaminated soils. Agronomy Journal. 108, 2: 540-547.

Eissa, M.A., Ahmed, E.M. 2016. Nitrogen and phosphorus fertilization for some Atriplex plants grown on metal-contaminated soils. Soil and Sediment Contamination: An International Journal. 25, 431-442.
Eissa, M.A., Suzie, M., Reichman, S.M. 2016. Production of the forage halophyte Atriplex amnicola in metal-contaminated soils. Soil Use and Management. 32, 350-356.

EU European Union. 2002. Heavy Metals in Wastes European Commission on Environment http: // ec.e uropa.eu/environment/waste/studies/pdf/ heavy metals report.pdf..

EU. European Union. 2006. Commission regulation EC. No. 1881/2006 of 19 December setting maximum levels for certain contaminants in foodstuffs. Official Journal of European Union L364/5.

Fakayode, S.O. 2005. Impact of industrial effluents on water quality of the receiving Alaro River in Ibadan, Nigeria. Ajeam-Ragee. 10, 1-13.

FAO. 1985. Water Quality for Agriculture. Paper No. 29 Rev. 1. UNESCO, Publication, Rome Anonymous, Annual Progress Report 2000-03. NATPMM Project on "Use of Urban and Industrial Effluents in Agriculture". CSSRI, Karnal-Haryana, India, 2004.

Faruqui, N.I., Scott, C.A., Raschid-sally, L. 2004. Confronting the realities of waste water in irrigated agriculture: lessons learned and recommendations. IDRC Books Free online. http://www.idrc.ca.

Ghimire, S.K. 1994. Evaluation of industrial effluents toxicity in seed germination and seedling growth of some vegetables, M.Sc. Dissertation, Central Department of Botany, Tribhuvan University, Kirtipur, Kathmandu, Nepal.

Ghosh, A.K., Bhatt, M.A., Agrawal, H.P. 2012. Effect of long-term application of treated sewage water on heavy metal accumulation in vegetables grown in northern India. Environ. Monit. Assess. 1842, 1025-1036.

Gupta, S.K., Scott, C., Mitra, A. 2011. Advances in Land Resource Management for 21st Century, Soil Conservation Society of India, New Delhi, India, 446-46. 
Huibers, F.P., Moscoso, O. A., Lier, J.B.V. 2004. The use of waste water in cochabamba, Bolivia: a degrading environment. IDRC Books Free online. http://www.idrc.ca.

Kadukova, J., Papadontonakis, N., Naxakis, G., Kalogerakis, N. 2004. Lead accumulation by the salttolerant plant Atriplex halimus. in: Moutzouris, C., Christodoulatos, C., Dermatas, D., Koutsospyros, A., Skanavis, C., Stamou, A., Eds. e-Proceedings of the International Conference on Protection and Restoration of the Environment VII, June 28-July 1, Mykonos, Greece.

Kanwar, J.S., Sandha, M.S. 2000. Waste water pollution injury to vegetable crops, a review. Agric. Review. 212, 133-136.

Khan, S.Q., Zheng, Y.M., Huang, Y.Z., Zhu, Y.G. 2008. Health risks of heavy metals in contaminated soils and food crops irrigated with wastewater in Beijing, China. Environ. Pollution. 1523, 686-692.

Khurana, M.P.S., Singh, P. 2012. Waste Water Use in Crop Production: A Review. Resources and Environment. 24, 116-131.

Lindsay, W.L., Norvell, W.A. 1969. Equilibrium relationship of $\mathrm{Zn}+2, \mathrm{Fe} 3+, \mathrm{Ca} 2+$ and $\mathrm{H}+$ with EDTA and DTPA in soils. Soil Sci. Soc. Am. J. $33,62-68$.

Lone, M.I., Saleem, S., Mahmood, T., Saifullah, K., Hussain, G. 2003. Heavy metal content of vegetables irrigated by sewage/tube well water. International J. Agric.\& Biol. 4, 533-535.

Marschner, H., 1995. Mineral nutrition of higher plants. Academic Press, London.

Qadir, M., Wichelns, D.L., Raschid-Sally, P.G., McCornick, P., Drechsel, A. B., Minhas, P.S. 2008. The challenges of wastewater irrigation in developing countries. Agric. Water Manag. http://www. sciencedirect.com.
Rattan, R.K., Datta, S.P., Chhonkar, P.K., Suribabua, K., Singh, A.K. 2005. Long-term impact of irrigation with sewage effluents on heavy metal content in soils, crops and groundwater-A case study. Agriculture, Ecosystems \& Environ. 109, 310-32.

Singh, A., Sharma, R.K., Agrawal, M., Marshall, F.M. 2010. Health risk assessment of heavy metals via dietary intake of foodstuffs from the wastewater irrigated site of a dry tropical area of India. Food Chem. Toxicol. 482, 611- 619.

US EPA. 1996. United States Environmental Protection Agency. Method 3050B. Acid digestion of sediments, sludges, and soils. USEPA; 1996.

Verdejo, J., Ginocchio, R., Sauve, S., Mondaca, P., Neaman, A. 2016. Thresholds of copper toxicity to lettuce in field-collected agricultural soils exposed to copper mining activities in Chile. J. Soil Sci. Plant Nutr. 16, 154-158

Voutsa, D., Grimanis, A., Samara, C. 1996. Trace elements in vegetables grown in an industrial area in relation to soil and air particulate matter. J. Environmental Pollution. 9434, 325-335.

WHO/FAO. 2007. Joint FAO/WHO Food Standard Programme Codex Alimentarius Commission 13th Session. Report of the Thirty Eight Session of the Codex Committee on Food Hygiene. Houston, United States of America, ALINORM 07/30/13.

Wozny, A. 1995. Lead in plant cells. Sorus, Poland. Wang, J.Q., Ru, S.H., Su, D.C. 2004. Effects of nitrogenous fertilizers and chelators on absorption of cadmium by indian mustard and oilseed rape. J Agro. Environ Sci. 23, 625-629. 